\title{
PENGGUNAAN TEPUNG LIMBAH PENETASAN TELUR PUYUH DALAM RANSUM TERHADAP KUALITAS FISIK TELUR PUYUH (Coturnix coturnix japonica)
}

\author{
S. Alamsyah ${ }^{1}$, S. Kismiati ${ }^{2}$ dan V. D. Yunianto ${ }^{2}$ \\ 1) Mahasiswa Fakultas Peternakan Dan Pertanian Universitas Diponegoro \\ Kampus drh. Soejono Koesoemowardojo Tembalang Semarang 50275 \\ E-mail: akusangmaestro@gmail.com \\ ${ }^{2)}$ Fakultas Peternakan dan Pertanian, Universitas Diponegoro \\ Kampus drh. R. Soejono Kusumowardojo Tembalang, Semarang 50275 \\ Diterima: 01 Agustus $2016 \quad$ Disetujui: 07 November 2016
}

\begin{abstract}
ABSTRAK
Penelitian bertujuan mengetahui pengaruh penggunaan tepung limbah penetasan telur puyuh dalam ransum terhadap kualitas fisik telur puyuh. Puyuh yang digunakan sebanyak 160 ekor puyuh betina (Coturnix coturnix japonica), umur 4 minggu dengan bobot badan rata-rata 94,19 7,36 g. Penelitian menggunakan Rancangan Acak Lengkap dengan 4 perlakuan dan 5 ulangan. Perlakuan terdiri dari T0: ransum tanpa tepung limbah penetasan, T1: ransum dengan tepung limbah penetasan 9\%, T2: ransum dengan tepung limbah penetasan 12\%, dan T3: ransum dengan tepung limbah penetasan $15 \%$. Setiap unit percobaan terdiri dari 8 ekor puyuh. Data yang diperoleh dianalisis ragam menggunakan uji $\mathrm{F}$ taraf $5 \%$. Hasil penelitian menunjukkan bahwa penggunaan tepung limbah penetasan telur puyuh dalam ransum tidak memberikan pengaruh nyata $(\mathrm{P}>0,05)$ terhadap berat telur, tebal kerabang, indeks putih telur, dan indeks kuning telur. Kesimpulan dari penelitian ini adalah penggunaan tepung limbah penetasan telur puyuh dapat digunakan dalam ransum sampai level 15\% tanpa merubah kualitas fisik telur puyuh.
\end{abstract}

Kata Kunci: puyuh, tepung limbah penetasan, kualitas fisik telur.

\section{EFFECT OF QUAIL HATCHERY WASTE MEAL IN THE DIET ON PHYSICAL QUALITY OF QUAIL EGG (COTURNIX COTURNIX JAPONICA}

\begin{abstract}
The experiment was aimed to study the effect of quail hatchery waste meal on physical qualities of quail eggs. Experiment used 160 japanese quails female, 4 weeks of age with average body weight $94.19 \pm 7.36$ g. Experiment used completely randomized design with 4 treatments and 5 replications. The treatment consisted of T0: ration without quail hatchery waste meal, T1: ration with 9\% quail hatchery waste meal, T2: ration with 12\% quail hatchery waste meal, and T3: ration with 15\% quail hatchery waste meal. Every unit treatments consists of 8 quails. Data obtained were analyzed by $F$ test level of 5\%. Results showed that treatment of quail hatchery waste meal had no significant effect on egg weight, shell thickness, albumin index, and yolk index. Conclusion of experiment
\end{abstract}


showed that treatment of quail hatchery waste meal can be used in the diet until 15\% without changed on physical quality of quail egg.

Keywords: quail, hatchery waste meal, physical quality of eggs.

\section{PENDAHULUAN}

Peningkatkan potensi produksi puyuh diperlukan manajemen yang baik terutama dari segi ransum. Ransum yang baik ialah yang mempunyai nilai gizi seimbang dan tepat. Ransum yang diberikan harus mengandung protein, lemak, karbohidrat, vitamin, dan mineral (Widodo, 2014). Ransum juga merupakan kendala utama dari peternak karena $70 \%$ biaya yang dikeluarkan peternak adalah untuk kebutuhan ransum (Abiola et al., 2012). Salah satu cara untuk menekan biaya ransum adalah dengan menggunakan bahan pakan non-konvensional berupa limbah.

Limbah penetasan puyuh meliputi cangkang dari telur yang telah menetas, embrio dalam telur yang mati, telur infertil serta anak puyuh yang mati (Shahriar et al., 2008). Limbah usaha penetasan puyuh sangat banyak yaitu sekitar $30-50 \%$ dari jumlah telur yang ditetaskan.

$$
\text { Limbah penetasan puyuh }
$$

mengandung protein dan kalsium yang tinggi. Kandungan protein kasar 36,24\%, serat kasar $0,92 \%$, kalsium $10,73 \%$, fosfor 0,69\%. Protein dan kalsium dibutuhkan untuk pembentukan telur. Pemberian tepung limbah penetasan dalam ransum puyuh breeder sampai level 9\% tidak berpengaruh nyata terhadap produksi telur, berat telur, konsumsi pakan, efisiensi pakan, serta tingkat hidup puyuh breeder (Sathishkumar dan Prabakaran, 2008).

Tujuan dari penelitian ini adalah untuk mengetahui pengaruh penggunaan tepung limbah penetasan telur puyuh terhadap kualitas fisik telur.

\section{MATERI DAN METODE}

Penelitian menggunakan 160 ekor puyuh betina (Coturnix coturnix japonica) berumur 4 minggu dengan bobot badan rata-rata 94,19 \pm 7,36 g, yang diperoleh dari Gajahan Colomadu, Kabupaten Karanganyar, Jawa Tengah. Limbah penetasan telur puyuh diperoleh dari Singopuran Kartasura, Kabupaten Sukoharjo, Jawa Tengah. Kandang yang digunakan adalah 2 kandang battery yang memiliki ukuran P x L x T $200 \mathrm{~cm}$ x $50 \mathrm{~cm}$ x $30 \mathrm{~cm}$ dan dibagi menjadi 10 petak.

Ransum yang digunakan dalam penelitian adalah jagung, polard, bungkil kedelai, Poultry Meat Meal (PMM), premix, kalsium karbonat $\left(\mathrm{CaCO}_{3}\right)$, Monocalcium Phosphate (MCP) dan tepung limbah penetasan telur puyuh (TLP). Prosedur pembuatan tepung limbah penetasan dapat dilihat pada Ilustrasi 1. 


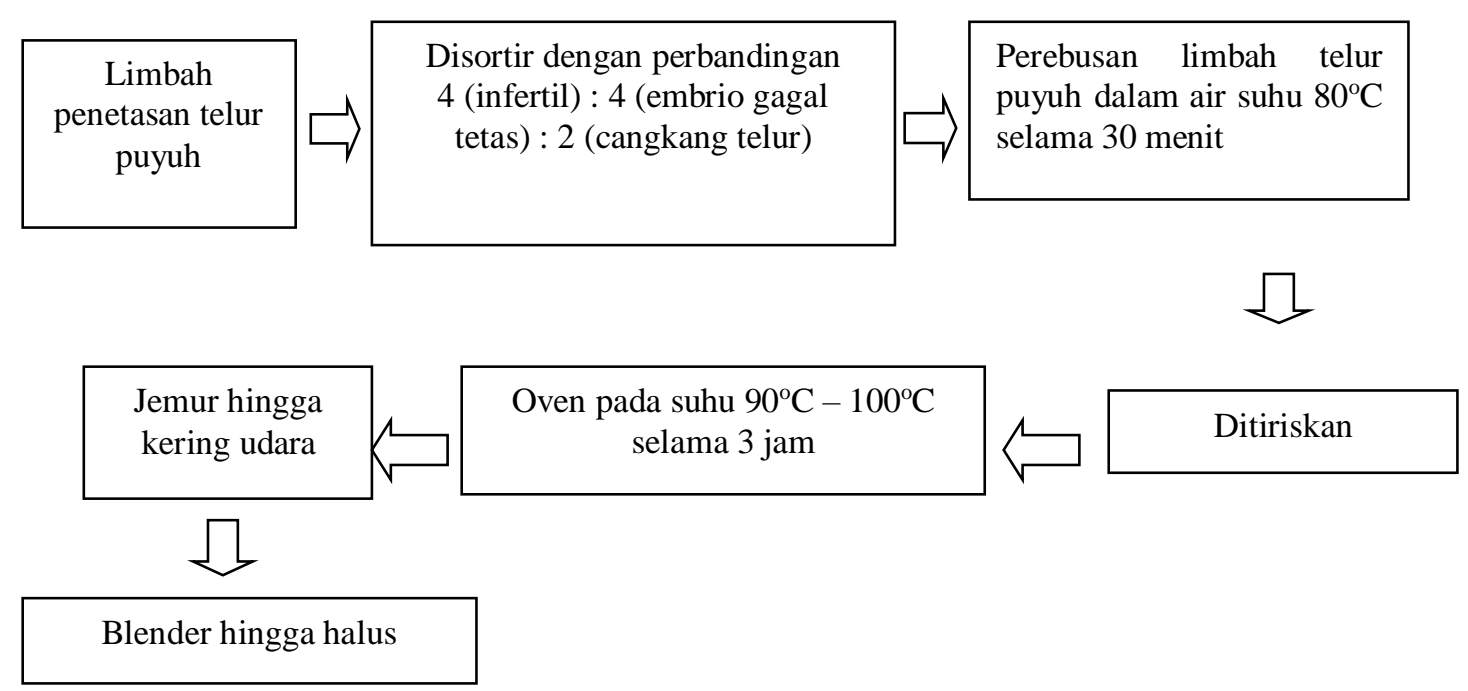

Ilustrasi 1. Alur Pembuatan Tepung Limbah Penetasan Telur Puyuh.

Tahap perlakuan dilaksanakan selama 7 minggu yaitu pada saat puyuh umur 8 minggu - 15 minggu. Pengambilan data dilakukan setiap hari terakhir selama 7 minggu. Parameter yang diamati meliputi berat telur, tebal kerabang, indeks putih telur, dan indeks kuning telur.

Penelitian menggunakan Rancangan Acak Lengkap (RAL) dengan 4 perlakuan dan 5 ulangan. Setiap unit percobaan terdiri dari 8 ekor puyuh betina. Perlakuan terdiri dari T0: ransum tanpa TLP, T1: ransum dengan TLP 9\%, T2: ransum dengan TLP 12\%, T3: ransum dengan TLP $15 \%$. Ransum percobaan dapat dilihat pada Tabel 1. Data yang diperoleh dianalisis ragam menggunakan uji $\mathrm{F}$ taraf 5\%.

Tabel 1. Komposisi dan Kandungan Nutrien Ransum Percobaan

\begin{tabular}{lcccc}
\hline \hline \multicolumn{1}{c}{ Bahan Pakan } & T0 $(\%)$ & T1 $(\%)$ & T2 $(\%)$ & T3 $(\%)$ \\
\hline Jagung & 45 & 46 & 48 & 43 \\
Polard & 21,25 & 19 & 15 & 20 \\
Bungkil Kedelai & 11 & 10 & 13 & 15,5 \\
PMM & 16 & 11 & 7,5 & 2,75 \\
Premix & 0,25 & 0,25 & 0,25 & 0,25 \\
$\mathrm{CaCO}_{3}$ & 5,5 & 3,25 & 2 & 1 \\
$\mathrm{MCP}$ & 1 & 1,5 & 2,25 & 2,5 \\
TLP & 0 & 9 & 12 & 15 \\
\hline Total & 100 & 100 & 100 & 100 \\
\hline Energi Metabolis (kkal/kg) & 3018,36 & 3077,11 & 3095,45 & 3099,47 \\
Protein Kasar (\%) & 21,78 & 21,77 & 21,88 & 21,96 \\
Lemak Kasar (\%) & 1,93 & 2,86 & 3,16 & 3,79 \\
Serat Kasar (\%) & 5,35 & 5,56 & 5,13 & 5,94 \\
Ca (\%) & 3,08 & 3,49 & 3,45 & 3,37 \\
P (\%) & 0,96 & 0,93 & 0,99 & 0,91 \\
\hline
\end{tabular}

*Bahan pakan hasil analisis Laboratorium Ilmu Nutrisi dan Pakan, Fakultas Peternakan dan Pertanian, Universitas Diponegoro, Semarang, 2015.

*Hasil perhitungan EM $(\mathrm{kkal} / \mathrm{kg})=40,81[0,87(\mathrm{PK}+2,25 \mathrm{x} \mathrm{LK}+\mathrm{BETN})+\mathrm{k}]$ rumus (Balton, 1967) dalam Indreswari et al. (2009). 


\section{HASIL DAN PEMBAHASAN}

Rataan berat telur, tebal kerabang, indeks putih telur, dan indeks kuning telur dapat dilihat pada Tabel 2.

Tabel 2. Rataan Berat Telur, Tebal Kerabang, Indeks Putih Telur, dan Indeks Kuning Telur Puyuh pada Level Penggunaan Tepung Limbah Penetasan Telur Puyuh yang Berbeda.

\begin{tabular}{clcccc}
\hline \multirow{2}{*}{ No } & \multirow{2}{*}{ Parameter } & \multicolumn{4}{c}{ Perlakuan } \\
\cline { 3 - 6 } & & T0 & T1 & T2 & T3 \\
\hline 1 & Berat Telur (g) & 9,38 & 9,57 & 9,76 & 10,08 \\
2 & Tebal Kerabang (mm) & 0,20 & 0,20 & 0,20 & 0,21 \\
3 & Indeks Putih Telur & 0,12 & 0,11 & 0,10 & 0,10 \\
4 & Indeks Kuning Telur & 0,49 & 0,47 & 0,49 & 0,47 \\
\hline
\end{tabular}

${ }^{\text {ns }}$ Non signifikan

\section{Berat Telur}

Hasil penelitian menunjukkan bahwa penggunaan TLP tidak berpengaruh nyata $(\mathrm{P}>0,05)$ terhadap berat telur. Hasil penelitian sesuai dengan Mahmud et al. (2015) bahwa penggunaan tepung limbah penetasan ayam pada ransum ayam petelur tidak berpengaruh nyata terhadap berat telur. Kandungan protein dan energi metabolis yang sama (isoprotein dan isoenergi) dalam ransum $\mathrm{T} 0, \mathrm{~T} 1, \mathrm{~T} 2$, dan T3 membuat berat telur tidak berbeda. Menurut Ghazvinian et al. (2011) bahwa penyusunan ransum dengan kandungan energi yang sama tidak memberi pengaruh nyata terhadap berat telur.

\section{Tebal Kerabang}

Tebal kerabang yang dihasilkan tidak berbeda nyata $(\mathrm{P}>0,05)$. Sesuai dengan Mahmud et al. (2015) bahwa penggunaan tepung limbah penetasan ayam terhadap ketebalan cangkang telur ayam tidak berbeda nyata. Penggunaan tepung limbah penetasan menurunkan jumlah $\mathrm{CaCO}_{3}$ dalam ransum. Menurut Setyaningrum et al. (2009) bahwa nilai pemanfaatan kalsium dipengaruhi oleh kandungan ion karbonat. Saadah (2008) menyatakan bahwa kandungan ion karbonat dalam $\mathrm{CaCO}_{3}$ cukup tinggi karena berperan penting sebagai sumber utama kalsium penyusun kerabang telur. Perbedaan jumlah komposisi $\mathrm{CaCO}_{3}$ dan TLP dalam ransum menjadikan nilai pemanfaatan kalsium kedua bahan ini menjadi tidak berbeda.

\section{Indeks Putih Telur}

Indeks putih telur tidak berbeda nyata $(\mathrm{P}>0,05)$. Hal ini dikarenakan ransum disusun dengan kandungan protein (isoprotein) dan energi metabolis (isoenergi) yang hampir sama. Menurut Argo et al. (2013) bahwa penyusunan ransum isoprotein memberikan hasil penelitian terhadap indeks putih telur relatif sama. Faktor lain yang menyebabkan nilai indeks putih telur tidak berbeda adalah berat telur yang dihasilkan tidak berbeda nyata. Juliambarwati (2010) menyatakan bahwa berat dari bagian telur mengikuti pola pertambahan dari berat telur, semakin berat telur maka bagian-bagian telur yang lain juga ikut meningkat.

\section{Indeks Kuning Telur}

Indeks kuning telur tidak berbeda nyata. Hal ini dipengaruhi oleh berat telur puyuh yang dihasilkan. Rata-rata berat telur yang dihasilkan tidak menunjukkan 
perbedaan yang nyata. Saadah (2008) menyatakan bahwa indeks kuning telur puyuh erat kaitannya dengan berat telur yang dihasilkan oleh puyuh. Semakin besar berat telur, maka kandungan putih telur dan kuning telur juga semakin besar. Faktor lain yang mempengaruhi nilai indeks kuning telur adalah protein. Hal ini karena protein berperan dalam membentuk kekuatan dan keadaan membran vitelin serta khalaza dalam mempertahankan kondisi kuning telur (Argo et al., 2013).

\section{SIMPULAN DAN SARAN \\ Simpulan}

Penggunaan tepung limbah penetasan telur puyuh dalam ransum sampai level $15 \%$ tidak dapat meningkatkan berat telur, tebal kerabang, indeks putih telur, dan indeks kuning telur.

\section{Saran}

Tepung limbah penetasan telur puyuh dapat digunakan dalam ransum sampai level 15\% tanpa merubah kualitas fisik telur.

\section{DAFTAR PUSTAKA}

Abiola, S.S., N.E. Radebe, C.V.D. Westhuizen, and D.O. Umesiobi. 2012. Whole hatchery waste meal as alternative protein and calcium sources in broiler diets. Arch. Zootec. 61 (234): 229 - 234.

Argo, L.B., Tristiarti, dan I. Mangisah. 2013. Kualitas fisik telur ayam arab petelur fase 1 dengan berbagai level Azolla microphylla. Anim. Agric. J. 2 (1): $445-457$.

Ghazvinian, K., M. Irani, R. Jamshidi, A. Mirzaei-Aghsaghali, S.A. Siadati, and A. Javaheri-Vaighan. 2011. The effect of energy to protein ratio on production performance and characteristics of Japanese quail eggs. Annals of Biological Res. 2 (2): 122 128.

Indreswari, R., H.I. Wahyuni, N. Suthama, dan P.W. Ristiana. 2009. Pemanfaatan kalsium untuk pembentukan cangkang telur akibat porsi pemberian ransum pagi dan siang pada ayam petelur. J. Indonesian Tropical Anim. Agric. 34 (2): $134-138$.

Juliambarwati, M. 2010. Pengaruh penggunaan tepung limbah udang dalam ransum terhadap kualitas telur itik. Skripsi. Fakultas Pertanian Universitas Sebelas Maret, Surakarta.

Mahmud, A., Saima, M. A. Jabbar, A. W. Sahota, Z. Hayat, and M.Z.U. Khan. 2015. Effect of feeding hatchery waste meal processed by different techniques on egg quality and production performance of laying hens. Pakistan J. Zool. 47 (4): 10591066.

Saadah, A. 2008. Pengaruh pemberian tepung bekicot (Achatina fulica) sebagai substitusi tepung ikan dalam ransum terhadap produksi dan kualitas telur pada burung puyuh (Coturnix coturnix japonica). Skripsi. Fakultas Sains dan Teknologi Universitas Islam Negeri Malang, Malang.

Sathishkumar, A. and R. Prabakaran. 2008. Recycling of Japanese quail hatchery waste on egg production performance of quail breeders. Tamilnadu J. Vet. and Anim. Sci. 4 (4): 123-128. 
Setyaningrum, S., H.I. Wahyuni, dan

Sukamto. 2009. Pemanfaatan kalsium kapur dan kulit kerang untuk pembentukan cangkang dan mobilisasi kalsium tulang pada ayam Kedu. Seminar Nasional Teknologi Peternakan dan Veteriner. Hal. 674681.

Shahriar, H.A., K. Nazer-Adl, J. Doolgarisharaf, and H. Monirifar. 2008. Journal of Anim. and Vet. Advances. 7 (1): 100-105.

Widodo, W. 2014. Ilmu Nutrisi Ternak Unggas. Universitas Muhammadiyah Malang Press, Malang. 